\title{
Effect of decocted turmeric on performance, hematological parameters and carcass traits of broiler chickens
}

\author{
I. Isroli*, T. Yudiarti, E. Widiastuti and S. Sugiharto \\ Faculty of Animal and Agricultural Sciences, Diponegoro University, \\ Tembalang Campus, Semarang 50275 - Indonesia \\ *CorrespondingE-mail: isroliundip02@yahoo.com
}

Received August 19, 2017; Accepted October 03, 2017

\begin{abstract}
ABSTRAK
Penelitian ini bertujuan mengkaji pengaruh pemberian dekok kunyit terhadap performa, parameter hematologis dan karakteristik karkas ayam broiler. Pada umur 11 hari, ayam didistribusikan secara acak ke dalam lima kelompok perlakuan, yaitu T0 (ayam diberi minum 100\% air), T1 (25\% dekok kunyit + $75 \%$ air), T2 (50\% dekok kunyit $+50 \%$ air), T3 (75\% dekok kunyit $+25 \%$ air) dan T4 (100\% dekok kunyit). Penelitian menggunakan rancangan acak lengkap (RAL), dengan parameter yang diamati meliputi performan, profil leukosit dan biokimia darah (total protein, albumin, globulin, asam urat, glukosa). Data dianalisis keragamannya pada taraf 5\%. Pemberian dekok kunyit tidak memberikan pengaruh terhadap pertambahan bobot badan, konsumsi pakan dan air serta konversi pakan ayam broiler. Proporsi limfosit lebih tinggi $(\mathrm{P}<0,05)$ pada ayam perlakuan $\mathrm{T} 1, \mathrm{~T} 2$ dan $\mathrm{T} 4$ dibandingkan dengan $\mathrm{T} 0$ dan T3. Rasio heterofil terhadap limfosit (H/L ratio) lebih rendah pada ayam yang diberi minum dekok kunyit dibandingkan dengan kontrol. Konsentrasi globulin lebih tinggi $(\mathrm{P}<0,05)$ dan rasio albumin terhadap globulin $(\mathrm{A} / \mathrm{G}$ ratio) lebih rendah $(\mathrm{P}<0,05)$ pada ayam perlakuan $\mathrm{T} 2$, T3 dan $\mathrm{T} 4$ jika dibandingkan dengan ayam T0 dan T1. Perlakuan tidak berdampak terhadap proporsi heterofil and konsentrasi total protein, albumin, asam urat dan glukosa pada serum. Jika dibandingkan dengan kontrol, bobot daging dada lebih tinggi pada ayam T3 dan lebih rendah pada T4. Sebagai kesimpulan, pemberian dekok kunyit melalui air minum dapat membantu memperbaiki respon stres dan meningkatkan daging dada ayam broiler
\end{abstract}

Kata Kunci: ayam broiler, biokimia darah, dekok kunyit, karkas, profil darah,

\begin{abstract}
This study aimed to investigate the effect of decocted turmeric on performance, haematological parameters and carcass traits of broilers. Broiler chicks at 11 days of age were allotted to five groups, including T0 (birds drinking 100\% water), T1 (25\% decocted turmeric $+75 \%$ water), T2 $(50 \%$ decocted turmeric $+50 \%$ water), T3 (75\% decocted turmeric $+25 \%$ water $)$ and $\mathrm{T} 4(100 \%$ decocted turmeric). The study was arranged based on a completely randomized design (CRD), parameters investigated was performance and blood chemistry (leukocyte, total protein, albumin, globulin, uric acid, glucose). The data were subjected to analysis of variance at $5 \%$ probability. Decocted turmeric did not affect weight gain, feed and water consumption and feed conversion ratio of broilers. Lymphocytes proportion was higher $(\mathrm{P}<0.05)$ in $\mathrm{T} 1, \mathrm{~T} 2$ and $\mathrm{T} 4$ than in $\mathrm{T} 0$ and $\mathrm{T} 3$ birds. The heterophils to lymphocytes ratio was lower $(\mathrm{P}<0.05)$ in birds receiving decocted turmeric than control. Globulin concentration and albumin to globulin ratio were higher and lower $(\mathrm{P}<0.05)$, respectively, in serum of $\mathrm{T} 2, \mathrm{~T} 3$ and $\mathrm{T} 4$ than $\mathrm{T} 0$ and $\mathrm{T} 1$ birds. The proportion of heterophils and concentration of serum total protein, albumin, uric acid and glucose were not different among treatments. The weight of breast meat was higher and lower $(\mathrm{P}<0.05)$
\end{abstract}


in T3 and T4 birds, respectively, compared to the control. In conclusion, providing decocted turmeric through drinking water helped to improve stress responses and increased the weight of breast meat of broiler chickens.

Keywords : blood count, broiler chick, carcass, decocted turmeric, serum biochemistry

\section{INTRODUCTION}

Turmeric (Curcuma longa) has widely been used for medicine both in humans and farm animals for long time. This plant may function as nematocide (Kiuchi et al., 1993), antibacterial, antifungal, antiprotozoal, antiviral and antioxidants (Chattopadhyay et al., 2004). Turmeric may also function as immunomodulatory (Ammon et al., 1993; Antony et al., 1999) and hypocholesteremic agents (Chattopadhyay et al., 2004). There are a number of active components in turmeric that can exert pharmaceutical effects, including tetrahydrocurcuminoid (Osawa et al., 1995), curcumin, demethoxycurcumin and bisdemethoxycurcumin (Wuthi-udomler et al., 2000). In poultry, several studies on turmeric (Al Sultan, 2003; Emadi and Kermanshahi, 2006; Arslan et al., 2017), have been conducted to improve the growth performance and health of broiler chickens. For instance, addition of $0.5 \%$ turmeric starch in the rations improved growth performance of broiler chickens (Al Sultan, 2003). The addition of $0.75 \%$ turmeric also decreased feed conversion ratio of broilers in the study of Emadi and Kermanshahi (2006). Moreover, supplementation of turmeric powder in the ration could improve antioxidant status and liver function, as well as decreased abdominal fat index without decreasing broiler performance (Hosseini-Vashan et al., 2012). More recent study further showed the efficacy of turmeric in improving the immune responses of broiler chicks (Arslan et al., 2017).

Commercial broiler farming is associated with a number of stresses that can ultimately compromise the health and productive performances of chicks (Surai, 2016). In such case, antioxidants is essential to protect the birds from oxidative damage (Sugiharto et al., 2017a). Broiler feeds available in the market have actually been supplemented with antioxidants. However, improper feed handling on the farm such as storage conditions may decrease the amounts and activity of antioxidant in feeds (Aviagen, 2014). The latter condition have encouraged the farmers to provide additional synthetic antioxidants that commercially available in the market. Indeed, there are several controversies regarding the use of synthetic antioxidants in broiler production, as they may have tumor-promoting activities and anti-carcinogenic properties (Baszczyk et al., 2013). Hence, any alternative for synthetic antioxidants for broilers are crucial. Taking the antioxidant capacity of turmeric into consideration, this medicinal plant may be beneficial for alleviating the negative effect of multiple stress on the growth performances and health of modern broiler strains.

Turmeric has generally been administrated in poultry rations in the form of extract (Sugiharto et al., 2011) or powder (Hosseini-Vashan et al., 2012). Turmeric extract is generally regarded more effective than powder. However, more effort and cost are needed to produce the extract of turmeric. For the latter reason, the use of turmeric extract in large-scale commercial broiler farming seems impractical. Boiling is a simple method that can be employed to enhance the functional properties of turmeric. In the previous study, Borde (2011) reported that boiling resulted in increased antioxidant activity of turmeric. Indeed, boiling may enhance the release of active compounds from the plant tissues. In relation to boiling, Simbo (2010) suggested that decoction (i.e., simple method of extraction by boiling plant materials and the remaining liquid is used for particular purpose) could be a preferred method to produce medicinal plant. Taking the advantages of boiling and the simple method of extraction, in the present study turmeric was decocted in water to produce "decocted turmeric". The latter product was provided to broiler chickens through drinking water. It was expected that decocted turmeric gave benefits to broiler chickens comparable to turmeric extract and better than turmeric powder. The aim of this present study was to investigate the effect of decocted turmeric on the performance, haematological parameters and carcass traits of broiler chickens.

\section{MATERIALS AND METHODS}

\section{Materials}

Fresh turmeric was obtained from a local 
market in Semarang. After being washed, turmeric was pounded with a pestle. Ten grams of pounded turmeric in $600 \mathrm{~mL}$ water was decocted for 10 min (Tantalo, 2010). The remaining liquid was then filtered using cheese cloth and let to cool. The product (decocted turmeric) was frozen until use. A total of 200 Lohmann (MB-202) 1-day-old broiler chicks were used in the present study. The chicks were raised in an open-sided naturally ventilated broiler house according to the standard rearing procedure of broiler chicks in Indonesia. From day 0 to 10 , the chicks were raised in a communal brooder.

\section{Methods}

The study was arranged based on a completely randomized design (CRD). At day 11, the chicks were weighed individually $(247 \pm 2.60$ g) and then randomly distributed to 25 rice hulllittered pens $(90 \times 60 \mathrm{~m})$ equipped with round bottom feeders and manual drinkers. Five pens (with 8 birds in each) per treatment were assigned to each of five experimental groups, including T0 (birds drinking 100\% water), T1 (birds drinking $25 \%$ decocted turmeric $+75 \%$ water), $\mathrm{T} 2$ (birds drinking $50 \%$ decocted turmeric $+50 \%$ water), T3 (birds drinking $75 \%$ decocted turmeric $+25 \%$ water) and T4 (birds drinking 100\% decocted turmeric). The feeds used in the present study were commercial feeds (Table 1) obtained from the local feed-mill industry. The birds were vaccinated with Newcastle Disease Virus (NDV) vaccine on day 1 and Gumboro vaccine on day 7 and 14 of the experiment. At day 28, blood was obtained from the bird's wing veins and collected in the vacutainer containing either ethylenediaminetetraacetic acid (EDTA) or no anticoagulant. The blood in EDTA-vacutainers were used directly to count heterophils and lymphocytes. The blood in vacutainer without anticoagulant was let to clot for $2 \mathrm{~h}$ at room temperature. After centrifugation at 2,000 rpm for $15 \mathrm{~min}$, the serum was obtained and frozen until serum biochemistry analysis. The enumeration of heterophils and lymphocytes, and the analysis of serum biochemistry were determined according to Sugiharto et al. (2017b). At day 32, the birds were slaughtered, de-feathered and eviscerated. Immediately, carcass and commercial cuts weight of broilers were determined.

\section{Data Analysis}

The study was arranged based on a completely randomized design, and the data obtained were analysed accordingly (Steel and Torrie, 1997). Pen was regarded as the experimental unit. Significant differences among experimental groups were further analysed with Duncan's multiple-range test. A significant level of $\mathrm{P}<0.05$ was implemented.

\section{RESULTS AND DISCUSSION}

\section{Results}

Performance of broilers. Data on the performances of broiler chicks are presented in Table 2. Drinking decocted turmeric did not affect the daily weight gain, feed consumption and feed conversion ratio of broiler chickens. The treatment also had no influence on the water consumption of broiler throughout the experimental period.

Haematological parameters of broilers. Table 3 shows the haematological parameters of broilers. In general, the proportion of lymphocytes was higher $(\mathrm{P}<0.05)$ in $\mathrm{T} 1, \mathrm{~T} 2$ and $\mathrm{T} 4$ birds compared to that in T0 and T3 birds. The heterophils to lymphocytes $(\mathrm{H} / \mathrm{L})$ ratio was lower $(\mathrm{P}<0.05)$ in the birds receiving decocted turmeric than that in control. The concentration of globulin and albumin to globulin $(\mathrm{A} / \mathrm{G})$ ratio were higher and lower $(\mathrm{P}<0.05)$, respectively, in the serum of $\mathrm{T} 2$, $\mathrm{T} 3$ and T4 birds when compared with that in T0 and $\mathrm{T} 1$ birds. The treatments had no effect on the proportion of heterophils and the concentration of serum total protein, albumin, uric acid and glucose of broilers.

Commercial cuts of broilers. The data on commercial cuts of broiler chickens are presented in Table 4. The weight of breast meat was higher and lower $(\mathrm{P}<0.05)$ in $\mathrm{T} 3$ and $\mathrm{T} 4$ birds, respectively, when compared with the control birds. There was no significant effect of decocted turmeric with regard to other commercial cuts of broiler chickens.

\section{Discussion}

In the present study, decocted turmeric did not have any effect on the final body weight, feed consumption and feed conversion ratio of broiler chicks. This present results were different from Rajput et al. (2013) reporting the enhancing effect of curcumin on broiler chickens. Indeed, our data were in accordance with Samarasinghe et al. (2003) showing the absence effect of turmeric root powder on weight gain, feed intake and feed 
conversion ratio of broilers. Hosseini-Vashan et al. (2012), also reported that feeding turmeric powder did not affect weigh gain, feed intake, feed conversion ratio and production index of broiler chickens. Concomitantly, Wang et al. (2015) reported that turmeric rhizome extract had no significant effect on the body weight of Wenchang broiler chickens. The exact rationale for the discrepancy results above remains unclear. However, the different nature (extract, powder or decocted) and levels of turmeric as well as trial conditions may be responsible. It has been suggested that the taste of turmeric may negatively affect the intake, which in turn reduced or had no effect on the growth rate of broilers (Hosseini-Vashan et al., 2012). However, the latter condition seemed not to occur in our study, as there was no difference in the water consumption among the treatment birds (turmeric

Table 1. Chemical Composition of Feeds ${ }^{\dagger}$

\begin{tabular}{lcc}
\hline \multicolumn{1}{c}{ Items (\%) } & Starter & Finisher \\
\hline Moisture & 13.0 & 13.0 \\
Crude protein & $21.0-23.0$ & $20.0-22.0$ \\
Crude lipid & 5.00 & 5.00 \\
Crude fiber & 5.00 & 5.00 \\
Ash & 7.00 & 8.00 \\
Calcium & 0.90 & 1.20 \\
Phosphor & 0.60 & 1.00 \\
\hline
\end{tabular}

${ }^{\dagger}$ Chemical compositions were obtained from feedmill industry had no effect on water consumption).

Drinking decocted turmeric resulted in increased proportion of lymphocytes in broiler chickens in the present study. This result was in accordance with the in vitro study by Lee et al. (2010) showing an increased lymphocytes proliferation (when compared with the control group) in spleen cells after exposure to turmeric powder. Considering the antioxidant (Chattopadhyay et al., 2004) and immunomodulatory effects of turmeric (Ammon et al., 1993; Antony et al., 1999), the increased proportion of lymphocytes seemed therefore to improve the immune system of broilers in the current study. The latter inference was supported by the fact that turmeric was capable of increasing the concentration of globulin (precursor for immunoglobulin production) in broilers in the current study. Moreover, the lower $\mathrm{A} / \mathrm{G}$ ratio in this study may further indicate the improvement of immune competence of decocted turmericdrunk broilers. Sugiharto et al. (2016a) suggested that the lower $\mathrm{A} / \mathrm{G}$ ratio implicates in a better immune competence and disease resistance of broilers. Interesting results was seen in the current study, in which drinking decocted turmeric was associated with the lower $\mathrm{H} / \mathrm{L}$ ratio of chickens. This present finding was in agreement with that of previously reported by Hosseini-Vashan et al. (2012) when feeding turmeric rhizome powder to broilers under heat stress conditions. The H/L ratio has commonly been used as an indicator of stress and infections in broilers (Sugiharto et al., 2016a; 2016b; 2017b). In this basis, decocted turmeric seemed beneficial in alleviating the stress and infections in broiler chickens. In this study, decocted turmeric did not influence the concentrations of total protein, albumin, uric acids

Table 2. Performances of Broiler Chickens

\begin{tabular}{|c|c|c|c|c|c|c|c|c|}
\hline \multirow{2}{*}{ Items } & \multicolumn{8}{|c|}{ Treatments } \\
\hline & \multicolumn{2}{|r|}{ T0 } & \multicolumn{2}{|r|}{$\mathrm{T} 1$} & $\mathrm{~T} 2$ & $\mathrm{~T} 3$ & \multicolumn{2}{|c|}{$\mathrm{T} 4$} \\
\hline DWG (g/bird/day) & 50.2 & \pm 0.82 & 51.3 & \pm 7.09 & $52.3 \pm 3.08$ & $51.3 \pm 2.48$ & $52.9 \pm$ & 5.14 \\
\hline DFI (g/bird/day) & 79.3 & \pm 1.72 & 80.0 & \pm 1.84 & $81.7 \pm 2.56$ & $82.3 \pm 2.68$ & $81.2 \pm$ & 3.79 \\
\hline FCR & 1.85 & $5 \pm 0.07$ & 1.86 & $5 \pm 0.32$ & $1.84 \pm 0.14$ & $1.90 \pm 0.17$ & $1.80 \pm$ & 0.16 \\
\hline DWI (mL/bird/day) & 225 & \pm 17.7 & 209 & \pm 58.3 & \pm 30.9 & \pm 67.4 & 227 & 111 \\
\hline
\end{tabular}

T0: birds drinking $100 \%$ water; T1: birds drinking $25 \%$ decocted turmeric $+75 \%$ water; T2: birds drinking $50 \%$ decocted turmeric $+50 \%$ water; T3: birds drinking $75 \%$ decocted turmeric $+25 \%$ water; T4: birds drinking 100\% decocted turmeric; DWG: daily weight gain; DFI: daily feed intake; FCR: feed conversion ratio; DWI: daily water intake. 
Table 3. Haematological Parameters of Broilers

\begin{tabular}{|c|c|c|c|c|c|}
\hline \multirow{2}{*}{ Items } & \multicolumn{5}{|c|}{ Treatments } \\
\hline & T0 & $\mathrm{T} 1$ & $\mathrm{~T} 2$ & $\mathrm{~T} 3$ & $\mathrm{~T} 4$ \\
\hline Lymphocytes $(\%)^{\dagger}$ & $51.8 \pm 6.49^{b}$ & $68.6 \pm 8.26^{\mathrm{a}}$ & $69.8 \pm 8.10^{\mathrm{a}}$ & $59.4 \pm 12.2^{b}$ & $67.4 \pm 10.6^{\mathrm{a}}$ \\
\hline Heterophils $(\%)^{\dagger}$ & $34.6 \pm 2.70$ & $24.0 \pm 11.2$ & $18.8 \pm 5.80$ & $23.2 \pm 10.5$ & $29.2 \pm 9.09$ \\
\hline $\mathrm{H} / \mathrm{L} \mathrm{ratio}^{\dagger}$ & $0.67 \pm 0.08^{\mathrm{a}}$ & $0.36 \pm 0.19^{b c}$ & $0.28 \pm 0.11^{\mathrm{c}}$ & $0.43 \pm 0.26^{b}$ & $0.46 \pm 0.24^{b}$ \\
\hline Total protein $(\mathrm{g} / \mathrm{dL})^{\ddagger}$ & $2.90 \pm 0.25$ & $2.63 \pm 0.15$ & $2.97 \pm 0.33$ & $3.10 \pm 0.44$ & $3.20 \pm 0.28$ \\
\hline $\operatorname{Albumin}(\mathrm{g} / \mathrm{dL})^{\ddagger}$ & $1.04 \pm 0.11$ & $0.92 \pm 0.09$ & $1.03 \pm 0.09$ & $0.99 \pm 0.14$ & $0.98 \pm 0.12$ \\
\hline Globulin $(\mathrm{g} / \mathrm{dL})^{\ddagger}$ & $1.87 \pm 0.22^{b}$ & $1.71 \pm 0.12^{\mathrm{b}}$ & $2.14 \pm 0.26^{\mathrm{a}}$ & $2.11 \pm 0.31^{\mathrm{a}}$ & $2.22 \pm 0.17^{\mathrm{a}}$ \\
\hline $\mathrm{A} / \mathrm{G}$ ratio & $0.56 \pm 0.08^{\mathrm{a}}$ & $0.54 \pm 0.06^{\mathrm{a}}$ & $0.48 \pm 0.04^{\mathrm{b}}$ & $0.47 \pm 0.04^{b}$ & $0.44 \pm 0.03^{b}$ \\
\hline Uric acid $(\mathrm{mg} / \mathrm{dL})^{*}$ & $4.14 \pm 2.40$ & $4.06 \pm 2.29$ & $3.91 \pm 2.31$ & $2.84 \pm 1.25$ & $3.00 \pm 1.38$ \\
\hline Glucose $(\mathrm{g} / \mathrm{dL})^{\ddagger}$ & \pm 22.8 & $217 \pm 22.7$ & \pm 35.4 & \pm 16.2 & \pm 62.4 \\
\hline
\end{tabular}

${ }^{\dagger}$ Assays were conducted in whole blood

*Assays were conducted in serum

T0: birds drinking $100 \%$ water; T1: birds drinking $25 \%$ decocted turmeric $+75 \%$ water; T2: birds drinking $50 \%$ decocted turmeric $+50 \%$ water; T3: birds drinking $75 \%$ decocted turmeric $+25 \%$ water; T4: birds drinking $100 \%$ decocted turmeric; $\mathrm{H} / \mathrm{L}$ ratio: heterophils to lymphocytes ratio; $\mathrm{A} / \mathrm{G}$ ratio: albumin to globulin ratio.

Table 4. Carcass and Commercial Cuts of Broilers ${ }^{\dagger}$

\begin{tabular}{|c|c|c|c|c|c|c|c|c|c|}
\hline \multirow{3}{*}{$\begin{array}{c}\text { Items } \\
\text { cass (g) }\end{array}$} & \multicolumn{9}{|c|}{ Treatments } \\
\hline & T0 & \multicolumn{2}{|r|}{$\mathrm{T} 1$} & \multicolumn{2}{|r|}{$\mathrm{T} 2$} & \multicolumn{2}{|r|}{$\mathrm{T} 3$} & \multicolumn{2}{|r|}{$\mathrm{T} 4$} \\
\hline & $836 \pm 47.4$ & 807 & \pm 104 & 851 & \pm 50.7 & 894 & \pm 80.6 & 773 & \pm 11.6 \\
\hline Wings (g) & $112 \pm 5.59$ & 110 & $\pm \quad 9.04$ & 111 & \pm 12.3 & 120 & \pm 12.3 & 108 & \pm 7.27 \\
\hline Breast (g) & $375 \pm 12.5^{\mathrm{b}}$ & 360 & $\pm 41.6^{\mathrm{bc}}$ & 396 & $\pm 23.2^{\mathrm{ab}}$ & 398 & $\pm 42.8^{\mathrm{a}}$ & 337 & $\pm 19.2^{c}$ \\
\hline Thigh (g) & $161 \pm 20.2$ & 152 & \pm 23.0 & 147 & \pm 31.6 & 168 & \pm 23.1 & 150 & \pm 8.26 \\
\hline Drum stick (g) & $146 \pm 11.6$ & 144 & \pm 22.8 & 150 & \pm 3.63 & 162 & \pm 13.5 & 142 & \pm 5.80 \\
\hline Shoulder (g) & $41.7 \pm 7.39$ & 40.5 & $\pm \quad 9.40$ & 47.2 & $2 \pm 5.34$ & 45.8 & $3 \pm 10.9$ & 37.0 & \pm 4.72 \\
\hline
\end{tabular}

${ }^{\dagger}$ Data are presented as absolute weight

T0: birds drinking $100 \%$ water; $\mathrm{T} 1$ : birds drinking $25 \%$ decocted turmeric $+75 \%$ water; $\mathrm{T} 2$ : birds drinking $50 \%$ decocted turmeric $+50 \%$ water; T3: birds drinking $75 \%$ decocted turmeric $+25 \%$ water; T4: birds drinking $100 \%$ decocted turmeric

and glucose in the serum of broiler chickens. These findings were in accordance with Ukoha dan Onunkwo (2016) reporting no significant effect of turmeric powder (up to $3 \%$ from total diets) on the serum total protein, glucose and cholesterol of broilers. In other study, HosseiniVashan et al. (2012) also reported no effect of turmeric powder on serum total protein of broilers.

Data in the current study showed that drinking decocted turmeric, especially for $75 \%$ decocted turmeric, increased the absolute weight of breast meat of broilers. This result was in agreement with Durrani et al. (2006) showing a higher relative weight of breast and thigh meats in turmeric powder fed broilers. Concomitantly, 
Wang et al. (2015) reported that supplementation with turmeric rhizome extract increased the absolute and relative weight of breast muscle of Wenchang broiler chickens. Regarding the negative effect of decocted turmeric, when provided at $100 \%$ in the drinking water, on the weight of breast muscle, this result was in contrast to the most of published reports earlier (HosseiniVashan et al., 2012; Wang et al., 2015). The definite explanation for this condition remains unclear, but the high concentration of curcumin in decocted turmeric might promote fat oxidation (Ejaz et al., 2009) in breast muscle, resulting in reduced weight of breast meats. This inference, however, should be taken with caution as breast muscle of broilers by nature contains less fat than other organs such as thigh, and therefore the effect of fat oxidation in breast muscle may be neglected. Apart from the significant effect on breast muscle, the effect of decocted turmeric was not significant with regard to other commercial cuts of broilers in the present study. The latter results were similar to those of previously reported (Durrani et al., 2006; Wang et al., 2015).

\section{CONCLUSION}

In conclusion, providing decocted turmeric through drinking water helped to improve immune competences and stress responses as well as increased the weight of breast meat of broiler chickens.

\section{REFERENCES}

Al Sultan, S.I. 2003. The effect of Curcuma longa (turmeric) on overall performances of broiler chicken. Int. J. Poult. Sci. 2:351-353.

Ammon, H.P., H. Safayhi, T. Mack and J. Sabieraj. 1993. Mechanism of antiinflammatory actions of curcumin and boswellic acids. J. Ethnopharmacol. 38:113119.

Anthony, S., R. Kuttan and G. Kuttan. 1999. Immunomodulatory activity of curcumin. Immunol. Invest. 28:291-303.

Arslan, M., A. ul Haq, M. Ashraf, J. Iqbal, and M.D. Mund. 2017. Effect of turmeric (Curcuma longa) supplementation on growth performance, immune response, carcass characteristics and cholesterol profile in broilers. Veterinaria. 66:16-20.

Aviagen. 2014. Ross broiler management handbook. www.aviagen.com
Baszczyk, A. A. Augustyniak and J. Skolimowski. 2013. Ethoxyquin: an antioxidant used in animal feed. Int. J. Food Sci. Vol. 2013, Article ID 585931, 12 pages http://dx.doi.org/10.1155/2013/585931

Borde, V.U. 2011. Effect of boiling and roasting on the antioxidants concentrations in extracts of fresh ginger (Zingiber officinale) and turmeric (Curcuma longa). Int. J. Ayurvedic Herb. Med. 1:46-50.

Chattopadhyay I., K. Biswas, U. Bandyopadhyay and R.K. Banerjee. 2004. Turmeric and curcumin: Biological actions and medicinal applications. Curr. Sci. 87(1):44-53.

Durrani, F.R., M. Ismail, A. Sultan, S.M. Suhail, N. Chand and Z. Durrani. 2006. Effect of different levels of feed added turmeric (Curcuma longa) on the performance of broiler chicks. J. Agric. Biol. Sci. 1:9-11.

Ejaz, A., D. Wu, P. Kwan and M. Meydani. 2009. Curcumin inhibits adipogenesis in 3T3-L1 adipocytes and angiogenesis and obesity in C57/BL mice. J. Nutr. 139:919-925.

Emadi, M. and H. Kermanshahi. 2006. Effect of turmeric rhizome powder on performance and carcass characteristics of broiler chicken. Int. J. Poult. Sci. 5:1069-1072.

Hosseini-Vashan, S.J., A. Golian, A. Yaghobfar, A. Zarban, N. Afzali and P. Esmaeilinasab. 2012. Antioxidant status, immune system, blood metabolites and carcass characteristic of broiler chickens fed turmeric rhizome powder under heat stress. Afr. J. Biotechnol. 11: 16118-16125.

Kiuchi, F., Y. Goto, N. Sugimoto, N, Akao, K, Kondo and Y. Tsuda. 1993. Nematocidal activity of turmeric and synergistic action of curcuminoids. Chem. Pharm. Bull. 41:16401643.

Lee, S.H., H.S. Lillehoj, S.I. Jang, D.K. Kim, C. Ionescu and D. Bravo. 2010. Effect of dietary curcuma, capsicum, and lentinus, on enhancing local immunity against Eimeria acervulina infection. J. Poult. Sci. 47:89-95.

Osawa, T., Y. Sugiyama, M. Inayoshi and S. Kawakishi. 1995. Antioxidative activity of etrahydrocurcuminoids. Biosci. Biotechnol. Biochem. 59:1609-1612.

Rajput, N., N. Muhammad, R. Yan, X. Zhong and T. Wang. 2013. Effect of dietary supplementation of curcumin on growth performance, intestinal morphology and nutrients utilization of broiler chicks. J. Poult. Sci. 50:44-52. 
Samarasinghe, K., C. Wenk, K.F.S.T. Silva and J.M.D.M. Gunasekera. 2003. Turmeric (Curcuma longa) root powder and mannanoligosaccharides as alternatives to antibiotics in broiler chicken diets. AsianAustral. J. Anim. Sci. 16:1495-1500.

Simbo, D.J. 2010. An ethnobotanical survey of medicinal plants in Babungo, Northwest Region, Cameroon. J. Ethnobiol. Ethnomed. 6:8.

Steel, R.G.D. and G.H. Torrie. 1997. Principles and procedures of statistics: a biometrical approach. McGraw-Hill, New York.

Sugiharto, S., Isroli, E. Widiastuti and N.S. Prabowo. 2011. Effect of turmeric extract on blood parameters, feed efficiency and abdominal fat content of broilers. J. Indon. Trop. Anim. Agric. 36:21-26.

Sugiharto S., T. Yudiarti and I. Isroli. 2016a. Performances and haematological profile of broilers fed fermented dried cassava (Manihot esculenta Crantz). Trop. Anim. Health Prod. 48:1337-1341.

Sugiharto, S., T. Yudiarti and I. Isroli. 2016b. Haematological and biochemical parameters of broilers fed cassava pulp fermented with filamentous fungi isolated from the Indonesian fermented dried cassava. Livest. Res. Rural Dev. 28(4)2016.

Sugiharto, S., T. Yudiarti, I. Isroli, E. Widiastuti,
E. Kusumanti. 2017a. Dietary supplementation of probiotics in poultry exposed to heat stress - a review. Ann. Anim. Sci. 17: 591-604.

Sugiharto, S., T. Yudiarti, I. Isroli, E. Widiastuti and F. D. Putra. 2017b. Intestinal microbial ecology and hematological parameters of broiler fed cassava waste pulp fermented with Acremonium charticola. Vet. World, 10:324-330.

Surai, P.F. 2015. Antioxidant systems in poultry biology: superoxide dismutase. J. Anim. Res. Nutr. 1:8.

Ukoha, Q.A. and D.N. Onunkwo, 2016. The effects of turmeric (Curcuma longa) on the haematology and blood chemistry of broiler chickens. Sci-Afric. J. Sci. Issues. Res. Essays. 4:963-968.

Wang, D., H. Huang, L. Zhou, W. Li, H. Zhou, G. Hou. 2015. Effects of dietary supplementation with turmeric rhizome extract on growth performance, carcass characteristics, antioxidant capability, and meat quality of Wenchang broiler chickens. Ital. J. Anim. Sci. 14:3.

Wuthi-udomler, M., W. Grisanapan, O. Luanrtana and W. Caichompoo. 2000. Antifungal Activity of Curcuma Longa Grown in Thailand. South East Asian J. Trop. Med. Public Health. 31:178-182. 